\title{
ESG Challenges in the Construction of UK Balanced Portfolios for Private Investors: An Analysis of the Availability and Performance of ESG Funds Across Various Asset Classes
}

\author{
Jacob H. Schmidt $\mathbf{P h D}^{1}$ and Charlie McCann ${ }^{2}$
}

\begin{abstract}
Environmental, Social and Governance (ESG) and sustainability investing have become very popular with institutional, family office and more recently, retail investors. In the UK the range of ESG and sustainable funds for retail and high net worth $(\mathrm{HNW})$ investors is still relatively small but growing fast. This paper studies both the supply side and risk-adjusted performance of ESG funds for UK retail investors.

Based on secondary data from the Financial Express (FE) Analytics database the authors find that funds in the equity, bond and multi-asset sector are investable, from qualitative as well as quantitative perspectives, but property, alternative and other asset classes are still underdeveloped. Choosing ESG objectives has provided better risk-adjusted returns over the long-term for the retail investor, but with a tilt towards the quality growth factor as ESG favors these sectors over typical old economy value. These findings are robust with top quartile rankings and the consistently higher Sharpe ratios over a 3-year period for the equity sectors. Due to the scarcity of bond funds and other diversifiers, portfolio construction is constrained. The authors predict that over time, availability of ESG funds in alternative asset classes will grow in line with demand.
\end{abstract}

JEL classification numbers: D61, G11, G14, G51, M14.

Keywords: Sustainable, Investment, ESG, Asset Management, Wealth, UK, Retail.

\footnotetext{
${ }^{1}$ Assistant Professor in Finance \& Deputy Director of the Faculty Centre for Applied Finance and Banking at Regent's University London, CEO of Schmidt Research Partners Limited, and Chief Investment Analyst at NLP Financial Management, London UK.

${ }^{2}$ Investment Analyst, NLP Financial Management, London, UK
}

Article Info: Received: December 21, 2021. Revised: January 22, 2022.

Published online: January 28, 2022. 


\section{Introduction}

ESG and Sustainability have become popular terms in the investment world, and in particular in the UK for retail investors. Diab and Martin Adams find that global sustainable invested assets can reach $\$ 37$ trillion by year-end 2021 and $\$ 53$ trillion by 2025 , with a $15 \%$ annualized growth rate since 2012, with Europe being the largest market in investable ESG assets, and USA the fastest growing market (Diab and Martin Adams, 2021). According to Boston Consulting Group ESG will continue to attract big inflows (Boston Consulting Group, 2019). Younger investors such as millennials and Generation $\mathrm{Z}$ showing interest in social, green and climate change issues increasingly request sustainable investment solutions (Ernst \& Young, 2017).

The development in ESG / sustainable funds can be compared to the stellar growth of alternative investment vehicles (hedge funds and absolute return funds) at the beginning of the $21^{\text {st }}$ century. From 2000-2008 the hedge fund industry grew significantly, only to disappoint in terms of performance in the Global Financial Crisis (Schmidt, 2017). Several papers were written on the proliferation of hedge funds and potential for performance disappointment (Schmidt, 2001).

Sustainable funds are investment products (pooled investments) selecting investments according to ESG criteria: Environmental, Social and Governmental. While the term ESG is relatively recent, the concept has been evolving since the early 1980s, formerly known as Social and Responsible Investing, ethical, green funds or religious investing (Sharia). Investors can choose passive investment solutions (trackers and Exchange traded funds (ETF)) or actively managed funds. The two main investment selection styles are negative exclusion-based and positive impact investing. There is a vast range of ESG indices covering the universe according to various exclusionary screening methodologies (Khajenouri and Schmidt, 2021). This leads to confusion and discussion over which indices to use. Active fund managers use criteria including exclusionary and impact investing when building portfolios.

UK retail investors who traditionally invest into regulated onshore unit trust (openended investment funds or mutual funds) or offshore funds, have access to a growing number of pooled investment vehicles offered in the UK as well as ETFs. This paper focuses on actively managed funds. 


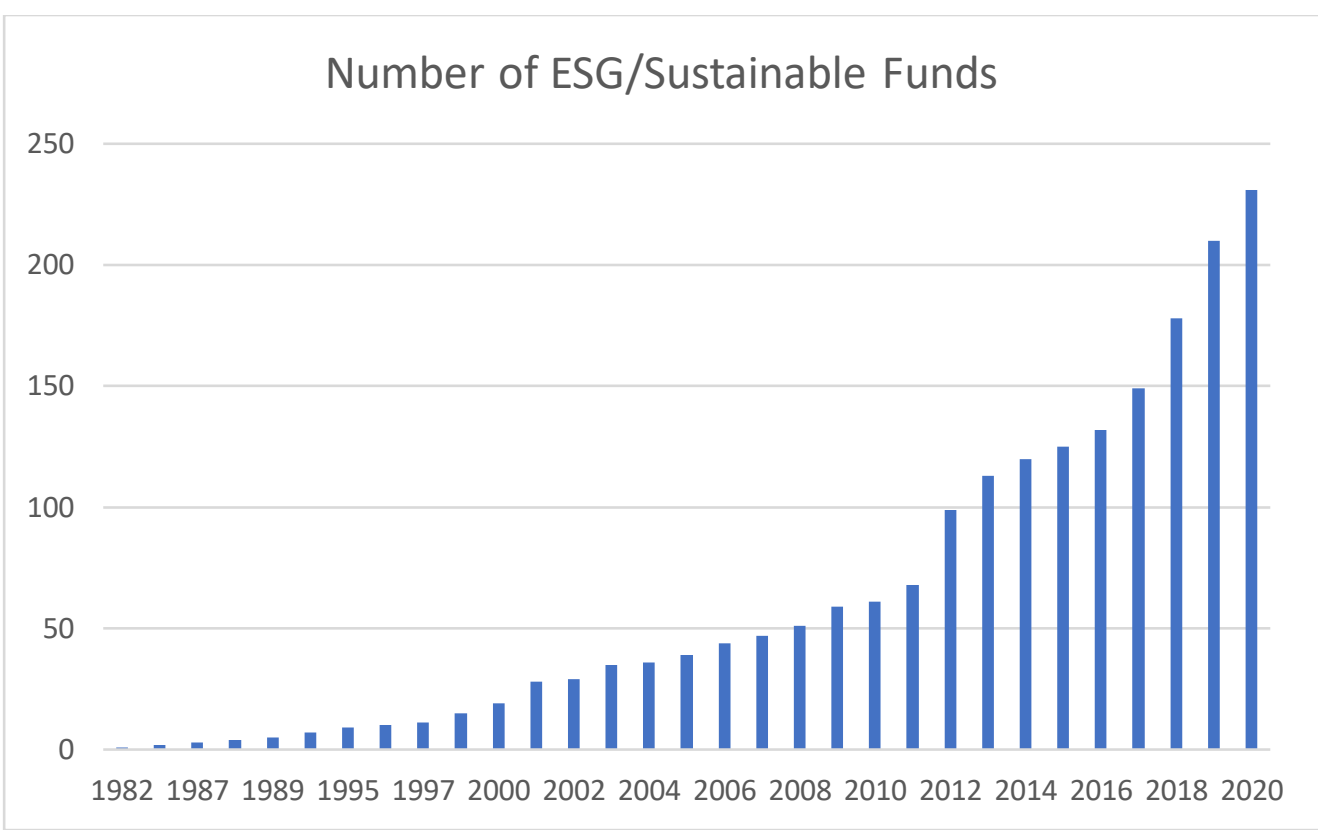

Figure 1: ESG Fund Launches 1982-2020 (Financial Express, 2021)

The number of sustainable funds available to UK retail investors has increased since 2010. In the past 5 years the trend has been accelerated due to a focus on all three ESG components.

This research design allows us to propose the following research question and related hypotheses:

HO1: due to the scarcity of ESG funds it is not possible to construct robust and diversified balanced portfolios of funds.

HA1: there are enough investable funds available to construct robust portfolios.

HO2: ESG funds do not outperform their conventional equivalent.

HA2: ESG funds outperform their conventional equivalents.

This subject has not been covered by the financial and environmental academic community. The researchers' motivations for covering this topic are the lack of current and specific academic coverage on the topic and the professional interest in sustainable investments and its relevant risk-adjusted returns.

\section{Literature Review}

The literature on ESG and sustainability has been mushrooming over the past 5 years. The asset management industry has been producing ESG surveys, analysis, white papers, market reports and specific research to educate investors, market their offerings and prove the concept, mainly from a performance perspective. Industry bodies and international organizations focus more on values and principles. On the academic side, studies range from value (econometric) and values (ethics and moral aspects) to structural aspects.

The leading investment house for UK retail funds, e.g., Aberdeen Standard 
(Aberdeen Standard Investments, 2021), BlackRock (BlackRock, 2020), Invesco (Invesco, 2021), JP Morgan AM (J.P. Morgan Asset Management, 2021), and Jupiter (Jupiter Asset Management, 2021), as well as smaller houses specialising in sustainability, e.g., Edentree (Edentree Investment Management, 2021) have dedicated websites and produce communications for intermediaries and investors. These resources are part educational and part promotional.

A survey of retail investors concluded that French and German retail investing into sustainability is important to them, with a key interest in environmental impact and less priority on outperformance (2 Investing Initiative, 2020). The Organisation for Economic Co-operation and Development (OECD) has been at the forefront of thought leadership with their catalogue of ESG principles. A recent report gives a systematic overview of practices and drivers of ESG investing (Boffo and Patalano, 2020).

In a recent study, individual ESG preferences revealed by retail mutual fund flows in the face of an economic crisis (e.g., Covid-19) showed fragile demand for ESG (Döttling and Kim, 2021). In a White Paper Cerulli Associates explore retail investors interest and demand for ESG and identify four driving forces, namely climate change and Covid-19 (as external factors) and wealth management and technology (secular trends in the industry) (Cerulli, 2021). Several studies discuss the performance attributes of ESG funds: many argue that ESG funds outperform non ESG and produce positive alpha (Di Lorenzo, Iacopino, Molino and Prosperi, 2020), while others disagree (Bruno, Esakia and Goltz, 2021).

The CFA Institute investigates the background and distinguishes six methods for ESG classifications (CFA Institute, 2021). The Investment Association in the UK identifies as the main drivers for ESG inflows climate change in 2019 and social impacts of business activities due to the pandemic (Covid-19) in 2020 (The Investment Association, 2020).

The UK Government wants an increase in the availability of sustainable investment product for the public (HM Government, 2019).

There is no research on the supply side of retail funds in ESG for UK investors. We intend to fill this gap with this paper.

\section{Data}

The industry body, the UK Investment Association looks after $£ 7$ trillion in assets (institutional and retail), over 4,800 funds and divides the industry into over 50 sectors. The sectors are a combination of asset-based (equities, bonds), geographyfocused and investment style targeted (The Investment Association, 2021). The Financial Express Analytics Database (FE) provides data on 4,833 onshore and offshore funds in 52 sectors (for UK retail investors with quantitative (performance) and qualitive data (FE Fundinfo, 2021). Advisors, managers, investors and other stakeholders (researchers, regulators et al) use the FE database - one of several - for analysis and investments. 
Monthly performance data based on closing prices in pound sterling, US dollars or Euro, for a common period of three years to July 2021 are used for all ESG and nonESG funds. Funds with a shorter track record are excluded.

\section{Research Method}

The research design is based on the authors' experience as academic researchers and professional analysts. The qualitative and quantitative data are used in the calculations of descriptive analytics, quartiles, Sharpe ratios and asset under management, style and other analyses. Sharpe ratios are calculated using a risk-free rate of zero due to interest rates having been at the zero bound for an extended period of time now. As the funds in FE have different inception dates and assetsunder-management, funds with a minimum track record of three years and assets of at least $£ 20$ million are filtered and used for this analysis. Most ESG funds have assets under management north of $£ 100 \mathrm{~m}$, with several in the multi-billion bracket. While ethical consideration should always be a focus in any research activity, due to the secondary data project there are such concerns applicable.

\section{Main Results}

\subsection{AUM of Funds in ESG Sectors}

As of data from 2021 from the Financial Express Analytics Database, there are 231 sustainable funds across 32 sectors in FE. Sustainable assets currently stand at $£ 190$ billion representing 5.5\% of assets of the UK retail fund market of $£ 3.482$ trillion. The equity sector is the largest with Global, Specialist, Emerging Markets and UK, follow by multi-assets (IA Mixed Investment 40-85\% Shares) and Sterling bonds. Absolute assets and property in ESG are small, but in some sectors the relative number (percentage of ESG vs total assets) appears to be larger, e.g., 40\% ESG funds in money markets. This can be explained by the asset class (money markets more likely to qualify as ESG) and the small number of total money market funds in the retail market. Contrary to institutional investors, such as banks, insurance and pension funds, retail investors prefer equity and other active funds over cash funds which yield zero to very low interest rates and are hence a performance drag. 
Table 1: ESG Sectors and AUM sorted by size as of July 2021

\begin{tabular}{l} 
Row Labels \\
FO Equity - Ethical \\
IA Asia Pacific Excluding Japan \\
IA Asia Pacific Including Japan \\
IA Europe Excluding UK \\
IA Europe Including UK \\
IA European Smaller Companies \\
IA Flexible Investment \\
IA Global \\
IA Global Corporate Bond \\
IA Global Emerging Markets \\
IA Global Equity Income \\
IA Global Government Bond \\
IA Global Mixed Bond \\
IA Japan \\
IA Mixed Investment 0-35\% Shares \\
IA Mixed Investment 20-60\% Shares \\
IA Mixed Investment 40-85\% Shares \\
IA North America \\
IA Property Other \\
IA Short Term Money Market \\
IA Specialist \\
IA Specialist Bond \\
IA Sterling Corporate Bond \\
IA Sterling High Yield \\
IA Sterling Strategic Bond \\
IA Targeted Absolute Return \\
IA UK All Companies \\
IA UK Direct Property \\
IA UK Equity Income \\
IA UK Smaller Companies \\
IA Unclassified \\
IA Volatility Managed \\
(blank) \\
\hline Grand Total ESG Sectors \\
IA
\end{tabular}

Grand Total ESG Sectors
-1 Sum of Fund Size (m)

£ 818

f $\quad 1,236$

£ 484

⿷ $\quad 1,783$

£ $\quad 1,566$

$£ \quad 672$

f $\quad 1,499$

f 62,155

£ $\quad 1,469$

$\pm \quad 12,356$

$\pm \quad 383$

£ 4,385

f $\quad 3,084$

£ $\quad 1,266$

f 1,203

f $\quad 5,305$

f 7,493

f $\quad 3,862$

$\mp \quad 87$

f $\quad 3,125$

£ 14,056

f 1,014

f 7,242

f $\quad 1,445$

f $\quad 1,956$

£ 881

f $\quad 8,877$

f $\quad 129$

£ 906

£ 28

f $\quad 37,876$

£ 738 $\mathbf{f}$

189,375

Grand Total all Sectors

$\mathbf{f}$

$3,482,468$ 
Table 2: All assets sorted by asset classes (as of July 2021)

All IA Sector Funds

\begin{tabular}{|l|r|r|}
\hline Asset Classes & AUM in $\mathrm{fm}$ & $\%$ \\
\hline & & \\
Cash & & \\
\hline Property & 45,743 & $1.31 \%$ \\
\hline Bonds & 32,356 & $0.93 \%$ \\
\hline Equities & 796,469 & $22.87 \%$ \\
\hline Absolute return & $2,371,943$ & $68.11 \%$ \\
\hline Multi-asset & 64,795 & $1.86 \%$ \\
\hline & 171,162 & $4.91 \%$ \\
\hline Total - all & $3,482,468$ & $100.00 \%$ \\
\hline
\end{tabular}

ESG IA Sector Funds

\begin{tabular}{|l|r|r|}
\hline Asset Classes & AUM in $\mathrm{fm}$ & $\%$ \\
\hline & & \\
Cash & 3,125 & $1.65 \%$ \\
\hline Property & 217 & $0.11 \%$ \\
\hline Bonds & 20,595 & $10.88 \%$ \\
\hline Equities & 150,558 & $79.50 \%$ \\
\hline Absolute return & 881 & $0.47 \%$ \\
\hline Multi-asset & 14,001 & $7.39 \%$ \\
\hline & & \\
\hline Total - ESG only & 189,375 & $100.00 \%$ \\
\hline
\end{tabular}

The table shows that most ESG funds are in the equity sector followed by bonds and multi asset funds. Data as of June 2021. For balanced investors who need an equity to bonds ratio of 50/50 or 60/40 this poses problems for diversification and volatility reduction options. 
Table 3: Asset Class \& Fund Availability (as of July 2021)

\begin{tabular}{|c|c|c|c|c|c|}
\hline & Sector & $\begin{array}{l}\text { ESG Sum of } \\
\text { Fund Size (m) }\end{array}$ & $\begin{array}{c}\text { Number of } \\
\text { ESG Funds in } \\
\text { Sector }\end{array}$ & $\begin{array}{c}\text { Total IA } \\
\text { Sector Fund } \\
\text { Size }(\mathbf{m})\end{array}$ & $\begin{array}{c}\text { Total } \\
\text { Number } \\
\text { of Funds } \\
\text { in IA } \\
\text { Sector }\end{array}$ \\
\hline \multirow{18}{*}{ 㴧 } & FO Equity - Ethical & 818 & 1 & N/A & N/A \\
\hline & IA Asia Pacific Excluding Japan & 1,236 & 2 & 74,252 & 124 \\
\hline & IA Asia Pacific Including Japan & 484 & 1 & 3,429 & 9 \\
\hline & IA China/Greater China & & & 25,026 & 56 \\
\hline & IA Europe Excluding UK & 1,783 & 8 & 107,594 & 144 \\
\hline & IA Europe Including UK & 1,566 & 6 & 77,199 & 86 \\
\hline & IA European Smaller Companies & 672 & 1 & 9,122 & 25 \\
\hline & IA Global & 62,155 & 61 & 515,820 & 458 \\
\hline & IA Global Emerging Markets & 12,356 & 8 & 137,885 & 149 \\
\hline & IA Global Equity Income & 383 & 2 & 20,719 & 57 \\
\hline & IA Japan & 1,266 & 2 & 58,656 & 91 \\
\hline & IA Japanese Smaller Companies & & & 2,260 & 8 \\
\hline & IA North America & 3,862 & 3 & 317,779 & 216 \\
\hline & IA North American Smaller Companies & & & 13,970 & 25 \\
\hline & IA Technology \& Telecommunications & & & 44,058 & 21 \\
\hline & IA UK AlI Companies & 8,877 & 18 & 202,277 & 254 \\
\hline & IA UK Equity Income & 906 & 5 & 47,346 & 86 \\
\hline & IA UK Smaller Companies & 28 & 1 & 20,753 & 50 \\
\hline \multirow{22}{*}{$\begin{array}{l}\text { 맘 } \\
\text { 을 }\end{array}$} & IA EUR Corporate Bond & & & 51,003 & 31 \\
\hline & IA EUR Government Bond & & & 27,620 & 31 \\
\hline & IA EUR High Yield Bond & & & 11,608 & 11 \\
\hline & IA EUR Mixed Bond & & & 9,039 & 11 \\
\hline & IA Global Corporate Bond & 1,469 & 1 & 45,960 & 25 \\
\hline & IA Global EM Bonds - Blended & & & 10,246 & 20 \\
\hline & IA Global EM Bonds - Hard Currency & & & 53,318 & 45 \\
\hline & IA Global EM Bonds - Local Currency & & & 29,240 & 35 \\
\hline & IA Global Government Bond & 4,385 & 1 & 16,610 & 20 \\
\hline & IA Global High Yield Bond & & & 29,543 & 26 \\
\hline & IA Global Inflation Linked Bond & & & 16,276 & 18 \\
\hline & IA Global Mixed Bond & 3,084 & 2 & 164,402 & 85 \\
\hline & IA Specialist Bond & 1,014 & 2 & 64,881 & 69 \\
\hline & IA Sterling Corporate Bond & 7,242 & 10 & 75,450 & 103 \\
\hline & IA Sterling High Yield & 1,445 & 3 & 18,773 & 34 \\
\hline & IA Sterling Strategic Bond & 1,956 & 3 & 52,972 & 89 \\
\hline & IA UK Gilts & & & 26,033 & 35 \\
\hline & IA UK Index Linked Gilts & & & 9,037 & 14 \\
\hline & IA USD Corporate Bond & & & 18,757 & 23 \\
\hline & IA USD Government Bond & & & 27,841 & 22 \\
\hline & IA USD High Yield Bond & & & 21,574 & 19 \\
\hline & IA USD Mixed Bond & & & 16,288 & 15 \\
\hline \multirow{5}{*}{ 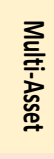 } & IA Flexible Investment & 1,499 & 5 & 58,452 & 159 \\
\hline & IA Mixed Investment 0-35\% Shares & 1,203 & 1 & 15,866 & 70 \\
\hline & IA Mixed Investment $20-60 \%$ Shares & 5,305 & 8 & 64,731 & 183 \\
\hline & IA Mixed Investment $40-85 \%$ Shares & 7,493 & 8 & 90,564 & 204 \\
\hline & IA Targeted Absolute Return & 881 & 3 & 64,795 & 108 \\
\hline \multirow{2}{*}{ 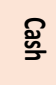 } & IA Short Term Money Market & 3,125 & 1 & 44,298 & 7 \\
\hline & IA Standard Money Market & & & 1,445 & 4 \\
\hline \multirow{2}{*}{ 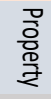 } & IA Property Other & 87 & 1 & 22,434 & 45 \\
\hline & IA UK Direct Property & 129 & 1 & 9,922 & 17 \\
\hline \multirow{6}{*}{$\frac{\text { 우 }}{\text { 혼 }}$} & IA Not yet assigned & & & 141 & 1 \\
\hline & IA Specialist & 14,056 & 16 & 174,895 & 310 \\
\hline & IA Unclassified & 37,876 & 39 & 400,410 & 911 \\
\hline & IA Volatility Managed & 738 & 7 & 59,904 & 174 \\
\hline & (blank) & & & & 1 \\
\hline & TOTAL: & 189,375 & 231 & $3,482,468$ & 4,834 \\
\hline
\end{tabular}

Table 3 gives a detailed view of the supply side as per the assets and number of funds in ESG and total assets and shows the scarcity of funds. 
Table 4: Asset Classes and Funds as of July 2021

\begin{tabular}{|l|r|l|r|r|r|r|r|}
\hline & Equities & Bonds & Multi-Asset & Cash & Property & Other \\
\hline Number of ESG Funds & 119 & 22 & 25 & 1 & 2 & 62 \\
\hline Total Number of Funds & 1859 & 781 & 724 & 11 & 62 & 1397 \\
\hline Total Number of Sectors & 18 & 22 & 5 & 2 & 2 & 5 \\
\hline Number of Sectors Without ESG Representation & 4 & 15 & 0 & 1 & 0 & 2 \\
\hline
\end{tabular}

Table 4 shows the number of funds and sectors in ESG and total universe.

Table 5: Largest ESG sectors (assets of $>£ 5$ b) (as of July 2021)

ESG IA Sectors with AUM $>£ 5 b$

\begin{tabular}{|l|r|r|l|}
\hline Name of ESG Sector & $\begin{array}{c}\text { AUM in } \\
\text { millions }\end{array}$ & $\begin{array}{c}\text { \% of ESG } \\
\text { Sector of } \\
\text { Total }\end{array}$ & Asset Class \\
\hline IA Global & 62,155 & $32.82 \%$ & Equities \\
\hline IA Unclassified & 37,876 & $20.00 \%$ & Equities \\
\hline IA Specialist & 14,056 & $7.42 \%$ & Equities \\
\hline IA Global Emerging Markets & 12,356 & $6.52 \%$ & Equities \\
\hline IA UK All Companies & 8,877 & $4.69 \%$ & Equities \\
\hline IA Mixed Investment 40-85\% Shares & 7,493 & $3.96 \%$ & Multi-asset \\
\hline IA Sterling Corporate Bond & 7,242 & $3.82 \%$ & Bonds \\
\hline IA Mixed Investment 20-60\% Shares & 5,305 & $2.80 \%$ & Multi-asset \\
\hline
\end{tabular}

\begin{tabular}{|l|r|r|l|}
\hline All other 24 smaller sectors & 34,016 & $18.00 \%$ & misc. \\
\hline
\end{tabular}

\begin{tabular}{|l|r|r|}
\hline Total & 189,375 & $100 \%$ \\
\hline
\end{tabular}

The table highlights the dominance of five equity sectors (Global, Unclassified, Specialist, EM and UK All Companies). Multi-asset funds and bonds are available but relatively small in comparison. Notably the assets in UK funds are small compared to the total market, due to the market composition (e.g., FTSE 100 consisting of many banks, miners, energy which do not meet ESG criteria). There is also a lack of North American Funds as US investors are lagging behind Europe in terms of ESG adoption.

Out of 231 ESG funds only 120 have a track record of at least three years. In addition, many funds are quite small. This limits the choice of funds further. 


\subsection{Descriptive Statistics of 8 major sectors in ESG vs entire sectors}

The four momenta of a normal distribution are calculated as well as the test for normality (the Jarque-Bera Test), Sharpe ratios and a t-test for the Sharpe ratios. Normality can be rejected in most cases at the $99 \%$ level. Sharpe ratios are significant at the $99 \%$ confidence interval.

\section{Tables 6: Descriptive Statistics of ESG and Non-ESG (for a 3-year period to July 2021)}

\begin{tabular}{|c|c|c|c|c|c|c|c|c|c|c|c|}
\hline & $\begin{array}{c}\text { Number of } \\
\text { Funds }\end{array}$ & CAGR & Volatility & $\begin{array}{l}\text { Sharpe } \\
\text { Ratio (SR) }\end{array}$ & t-statistic & $\begin{array}{c}\text { Sign. of } \\
\text { SR }\end{array}$ & Skew & Kurt & $\begin{array}{c}\text { Jarque- } \\
\text { Bera (JB) } \\
\text { Test } \\
\text { Statistic } \\
\end{array}$ & JB p-value & $\begin{array}{c}\text { Sign. of } \\
\text { JB }\end{array}$ \\
\hline IA Global & 383 & $13.32 \%$ & $15.90 \%$ & 0.87 & 3.92 & ** & 0.45 & 1.09 & 7.74 & 0.020893 & $* *$ \\
\hline IA Global - ESG & 45 & $16.47 \%$ & $15.49 \%$ & 1.07 & 6.43 & ** & 0.49 & 0.99 & 7.54 & 0.02308 & $*$ \\
\hline IA Unclassified & 627 & $4.83 \%$ & $9.86 \%$ & 0.55 & 3.79 & ** & 1.99 & 9.09 & 193.49 & $9.64 \mathrm{E}-43$ & $* *$ \\
\hline IA Unclassified - ESG & 21 & $7.88 \%$ & $11.59 \%$ & 0.74 & 4.45 & ** & 1.00 & 3.96 & 71.38 & $3.17 E-16$ & $* *$ \\
\hline IA Specialist & 287 & $6.83 \%$ & $18.23 \%$ & 0.44 & 3.00 & ** & 1.48 & 5.75 & 87.43 & $1.03 E-19$ & $* *$ \\
\hline IA Specialist - ESG & 16 & $9.17 \%$ & $17.27 \%$ & 0.61 & 3.67 & $* *$ & 0.88 & 3.03 & 37.04 & $9.05 E-09$ & $* *$ \\
\hline IA Global Emerging Markets & 127 & $8.49 \%$ & $16.59 \%$ & 0.51 & 2.64 & ** & 0.83 & 2.18 & 16.82 & 0.000222 & $* *$ \\
\hline IA Global Emerging Markets - ESG & 6 & $7.40 \%$ & $15.28 \%$ & 0.48 & 2.88 & $* *$ & 0.62 & 1.10 & 5.08 & 0.078947 & \\
\hline IA UK All Companies & 238 & $5.92 \%$ & $19.25 \%$ & 0.31 & 2.53 & $* *$ & 0.68 & 3.89 & 30.16 & $2.83 \mathrm{E}-07$ & $* *$ \\
\hline IA UK All Companies & 16 & $8.41 \%$ & $18.10 \%$ & 0.47 & 2.80 & ** & 0.71 & 3.57 & 25.01 & $3.7 E-06$ & $* *$ \\
\hline IA Mixed Investment 40-85\% Shares & 167 & $6.97 \%$ & $11.75 \%$ & 0.61 & 3.03 & ** & 0.97 & 3.69 & 38.69 & $3.96 \mathrm{E}-09$ & $* *$ \\
\hline IA Mixed Investment 40-85\% Shares & 8 & $11.83 \%$ & $11.07 \%$ & 1.05 & 6.32 & ** & 0.71 & 1.98 & 14.08 & 0.000875 & $* *$ \\
\hline IA Sterling Corporate Bond & 98 & $5.40 \%$ & $6.07 \%$ & 0.89 & 5.45 & ** & 1.69 & 8.33 & 160.09 & $1.73 E-35$ & $* *$ \\
\hline IA Sterling Corporate Bond & 10 & $4.86 \%$ & $5.14 \%$ & 0.95 & 5.71 & ** & 2.01 & 9.43 & 177.55 & $2.79 E-39$ & $* *$ \\
\hline IA Mixed Investment 40-85\% Shares & 167 & $6.81 \%$ & $11.77 \%$ & 0.60 & 3.03 & ** & 1.07 & 3.93 & 84.91 & $3.65 E-19$ & $* *$ \\
\hline IA Mixed Investment 20-60\% Shares & 6 & $0.08 \%$ & $0.09 \%$ & 0.88 & 5.28 & ** & 0.72 & 2.88 & 19.34 & $6.31 \mathrm{E}-05$ & $* *$ \\
\hline
\end{tabular}

\begin{tabular}{ll}
\hline Significance Levels & $* 95 \%$ \\
& $* 99 \%$
\end{tabular}

The Sharpe ratios for ESG funds are better than for non-ESG funds across all sectors, except for the IA Emerging Markets Sector which has a small number of funds with the required 3-year track record. Because there are very few ESG funds with a 5year history available to UK retail investors we did not include them in our analysis. Over a 1-year period ESG funds tended to outperform, despite the rotation into value sectors which are typically not held by ESG managers, such as oil \& gas. 


\subsection{Quartiles}

The analysis of performance quartiles is used to show how ESG funds were performing versus the entire sector. While 3-year numbers are in general more reliable due to the larger number of data points (36 monthly observations), the 1year number (12 monthly data points) are relevant for our analysis as there was an equity markets sector and style rotation from quality growth to value stocks in the middle of this 1-year period. Quality growth stocks performed well from May November 2020 while value stocks took off with the news of approved vaccines in November 2020.

Table 7: Quartiles of ESG Sector Funds over 1 year to the end of July 2021

\begin{tabular}{|c|c|c|c|c|c|}
\hline \multicolumn{6}{|c|}{ Quartiles 1 year } \\
\hline \multicolumn{3}{|c|}{ IA Global } & \multicolumn{3}{|c|}{ IA Global Emerging Markets } \\
\hline \multicolumn{3}{|c|}{ Total 471; 61 ESG; 61 ESG with 1 year } & \multicolumn{3}{|c|}{ Total 152; 8 ESG; 8 ESG with 1 year } \\
\hline Quartiles & Count & & Quartiles & Count & \\
\hline 1 & 18 & $29.5 \%$ & 1 & 3 & $37.5 \%$ \\
\hline 2 & 14 & $23.0 \%$ & 2 & 1 & $12.5 \%$ \\
\hline 3 & 17 & $27.9 \%$ & 3 & 2 & $25.0 \%$ \\
\hline 4 & 12 & $19.7 \%$ & 4 & 2 & $25.0 \%$ \\
\hline TOTAL: & 61 & $100.0 \%$ & TOTAL: & 8 & $100.0 \%$ \\
\hline \multicolumn{3}{|c|}{ IA UK All Companies } & \multicolumn{3}{|c|}{ IA Sterling Corporate Bond } \\
\hline \multicolumn{3}{|c|}{ Total 253; 18 ESG; 17 ESG with 1 year } & \multicolumn{3}{|c|}{ Total 103; 10 ESG; 10 ESG with 1 year } \\
\hline Quartiles & Count & & Quartiles & Count & \\
\hline 1 & 7 & $41.2 \%$ & 1 & 2 & $20.0 \%$ \\
\hline 2 & 4 & $23.5 \%$ & 2 & 1 & $10.0 \%$ \\
\hline 3 & 0 & $0.0 \%$ & 3 & 3 & $30.0 \%$ \\
\hline 4 & 6 & $35.3 \%$ & 4 & 4 & $40.0 \%$ \\
\hline TOTAL: & 17 & $100.0 \%$ & TOTAL: & 10 & $100.0 \%$ \\
\hline \multicolumn{3}{|c|}{ IA Mixed Investment $40-85 \%$ Shares } & \multicolumn{3}{|c|}{ IA Mixed Investment $20-60 \%$ Shares } \\
\hline \multicolumn{3}{|c|}{ Total 203; 8 ESG; 8 ESG with 1 year } & \multicolumn{3}{|c|}{ Total 183; 8 ESG; 8 ESG with 1 year } \\
\hline Quartiles & Count & & Quartiles & Count & \\
\hline 1 & 6 & $75.0 \%$ & 1 & 6 & $75.0 \%$ \\
\hline 2 & 2 & $25.0 \%$ & 2 & 0 & $0.0 \%$ \\
\hline 3 & 0 & $0.0 \%$ & 3 & 1 & $12.5 \%$ \\
\hline 4 & 0 & $0.0 \%$ & 4 & 1 & $12.5 \%$ \\
\hline TOTAL: & 8 & $100.0 \%$ & TOTAL: & 8 & $100.0 \%$ \\
\hline
\end{tabular}


Table 8: Quartiles of ESG Sector Funds over 3 years

\begin{tabular}{|c|c|c|c|c|c|}
\hline \multicolumn{6}{|c|}{ Quartiles 3 years } \\
\hline \multicolumn{3}{|c|}{ IA Global } & \multicolumn{3}{|c|}{ IA Global Emerging Markets } \\
\hline \multicolumn{3}{|c|}{ Total 471; 61 ESG; 45 ESG with 3 years } & \multicolumn{3}{|c|}{ Total 152; 8 ESG; 3 ESG with 3 years } \\
\hline Quartiles & Count & & Quartiles & Count & \\
\hline 1 & 21 & $46.7 \%$ & 1 & 1 & $12.5 \%$ \\
\hline 2 & 15 & $33.3 \%$ & 2 & 1 & $12.5 \%$ \\
\hline 3 & 5 & $11.1 \%$ & 3 & 1 & $12.5 \%$ \\
\hline 4 & 4 & $8.9 \%$ & 4 & 0 & $0.0 \%$ \\
\hline TOTAL: & 45 & $100.0 \%$ & TOTAL: & 3 & $100.0 \%$ \\
\hline \multicolumn{3}{|c|}{ IA UK All Companies } & \multicolumn{3}{|c|}{ IA Sterling Corporate Bond } \\
\hline \multicolumn{3}{|c|}{ Total 253; 18 ESG; 16 ESG with 3 years } & \multicolumn{3}{|c|}{ Total 103; 10 ESG; 10 ESG with 3 years } \\
\hline Quartiles & Count & & Quartiles & Count & \\
\hline 1 & 7 & $43.8 \%$ & 1 & 1 & $10.0 \%$ \\
\hline 2 & 5 & $31.3 \%$ & 2 & 5 & $50.0 \%$ \\
\hline 3 & 2 & $12.5 \%$ & 3 & 1 & $10.0 \%$ \\
\hline 4 & 2 & $12.5 \%$ & 4 & 3 & $30.0 \%$ \\
\hline TOTAL: & 16 & $100.0 \%$ & TOTAL: & 10 & $100.0 \%$ \\
\hline \multicolumn{3}{|c|}{ IA Mixed Investment $40-85 \%$ Shares } & \multicolumn{3}{|c|}{ IA Mixed Investment $20-60 \%$ Shares } \\
\hline \multicolumn{3}{|c|}{ Total 203; 8 ESG; 8 ESG with 3 years } & \multicolumn{3}{|c|}{ Total 183; 8 ESG; 6 ESG with 3 years } \\
\hline Quartiles & Count & & Quartiles & Count & \\
\hline 1 & 6 & $75.0 \%$ & 1 & 4 & $66.7 \%$ \\
\hline 2 & 1 & $12.5 \%$ & 2 & 2 & $33.3 \%$ \\
\hline 3 & 1 & $12.5 \%$ & 3 & 0 & $0.0 \%$ \\
\hline 4 & 0 & $0.0 \%$ & 4 & 0 & $0.0 \%$ \\
\hline TOTAL: & 8 & $100.0 \%$ & TOTAL: & 6 & $100.0 \%$ \\
\hline
\end{tabular}

The majority of ESG equity funds (IA Global, IA Global Emerging markets, IA UK All Companies) are in the 1st and 2nd Quartiles for both 1 year and three years data. Bond funds in the Sterling Corporate sector are small in absolute number and total assets. These bond funds with less than a three-year track record are mainly in the $3^{\text {rd }}$ and $4^{\text {th }}$ quartile, while those with a three-year track record are also not significantly outperforming. Very interesting to see that a majority of the multi asset funds (mixed $20-60 \%$ and $40-85 \%$ ) are in the 1st Quartile over both one-year and three-year periods. The authors did not find justification for including the IA Specialist sector in this analysis as no quartiles are calculated due to the wide definition of funds in the sector. In conclusion: while equity and multi-asset funds are performing well against their non-ESG peers, bond funds are finding it more difficult to outperform. 
As seen above, regardless of the ESG investment style, funds in these sectors consistently exhibit higher Sharpe ratios. This reinforces to reject hypothesis HO2 that ESG funds do not outperform their conventional equivalents.

\section{Conclusion}

The results lead to a rejection of the hypotheses that ESG funds are underperforming. While the number of investable funds is low relative to the whole of market, the Sharpe ratios and quartile analyses underline the strong outperformance of ESG equity and multi-asset funds. It is important to note the space is still very much in its infancy, with few ESG funds having a track record past five years. As a result, the analysis was conducted over a three-year period. The period from June 2018 until November 2020 was a particularly favourable time for growth sectors such as IT and healthcare, which tend to feature heavily in ESG portfolios, versus value sectors such as oil \& gas and mining, which are almost always excluded from them. This timeframe also coincided with a general move into ESG investing from institutions, wealth managers and retail clients alike, and as such stocks which were considered to be ESG leaders saw material share price momentum. However, since the November 2020 vaccine announcements, there has been a rotation into valuedominated sectors and away from quality growth. Despite that, the ESG equity and multi-asset funds included in our analysis mostly sit in the first and second quartiles over a one year period. The authors did not find enough evidence to reject the first hypothesis regarding the scarcity of available funds to construct a robust, balanced portfolio. The issue of a small number of bonds and their weaker performance makes it more difficult to construct balanced, more defensive or cautious portfolios. However, many young investors are long-term investors and often more open to volatility (as a measure of risk) and have larger allocations into equities than the $60 / 40$ traditional balanced portfolio asset allocation. We conclude that as the ESG fund universe will continue to grow and produce more investable funds in all sectors, the construction of diversified portfolios will become easier. Future research will focus on ESG investment considerations in the context of portfolio construction as well as institutional and family office investors who have different risk profiles and appetites. 


\section{References}

[1] 2 Investing Initiative. (2020). A Large Majority of Retail Clients Want to Invest Sustainably. Survey of French and German retail investors' sustainability objectives. https://2degrees-investing.org/resource/retailclients-sustainable-investment/ [Accessed 4 Aug 2021]

[2] Aberdeen Standard. Sustainable Investing. Invest today. Change tomorrow. https://www.aberdeenstandard.com/en/responsible-investing [Accessed 8 Aug 2021]

[3] BlackRock. BlackRock Official Site - Sustainable Investing. Available at https://www.blackrock.com/uk/individual/about-us/sustainability-resilienceresearch [Accessed 8 Aug 2021]

[4] Boffo, R., and R. Patalano (2020). "ESG Investing: Practices, Progress and Challenges", OECD Paris. www.oecd.org/finance/ESG-Investing-PracticesProgress-and-Challenges.pdf [Accessed 4 Aug 2021]

[5] Boston Consulting Group. (2019). How Sustainable Finance Is Shifting the Future of Investing.

[6] Bruno, G. Esakia, M. and Goltz, F. (2021). "Honey, I Shrunk the ESG Alpha": Risk-Adjusting ESG Portfolio Returns. Edhec. Available from https://www.scientificbeta.com > factor > download [Accessed 4 Aug 2021]

[7] Cerulli. Global Retail Investors and ESG https://www.cerulli.com/knowledge/white-paper-global-retail-investors-andesg [Accessed 8 Aug 2021]

[8] CFA Institute. ESG Issues in Investing. A Guide for Investment Professionals. Available from https://www.cfainstitute.org/en/research/esg-investing [Accessed 4 Aug 2021]

[9] Data Provided. FE Fundinfo. Available from https://www.fe-fundinfo.com

[10] Diab, A. Martin Adams, G. (2021). ESG assets may hit $\$ 53$ trillion by 2025, a third of global AUM. Bloomberg Intelligence. February 23, 2021. Available from https://www.bloomberg.com/professional/blog/esg-assets-may-hit-53trillion-by-2025-a-third-of-global-aum/ [Accessed 3 Aug 2021]

[11] Di Lorenzo, V. Iacopino, A. Molino, A. Prosperi, L. (2020). Prometeia. https://www.bobsguide.com/articles/retail-esg-mutual-funds-have-betterfinancial-performances-but-monitoring-supply-is-needed/ [Accessed 4 Aug 2021]

[12] Döttling, Robin and Kim, Sehoon, Sustainability Preferences Under Stress: Evidence from Mutual Fund Flows During COVID-19 (May 5, 2021).

Available at SSRN: https://ssrn.com/abstract=3656756 or http://dx.doi.org/10.2139/ssrn.3656756 [Accessed 8 Aug 2021]

[13] EdenTree. Available at https://www.edentreeim.com/ [Accessed 8 Aug 2021]

[14] Ernst \& Young. (2017). Sustainable Investing: The Millennial Investor.

[15] HM Government. Department for International Development. (2019). INVESTING IN A BETTER WORLD: Understanding the UK public's demand for opportunities to invest in the Sustainable Development Goals. 
Available from https://www.gov.uk/government/publications/investing-in-abetter-world-results-of-uk-survey-on-financing-the-sdgs [Accessed 8 Aug 2021]

[16] Invesco. Environmental, Social and Governance. Available at https://www.invesco.com/corporate/about-us/esg [Accessed 8 Aug 2021]

[17] J.P. Morgan. Sustainable investing. Plan for the future you want to see. Available at

[18] https://am.jpmorgan.com/gb/en/asset-management/adv/investmentthemes/sustainable-investing/ [Accessed 3 Aug 2021]

[19] Jupiter. ESG \& Stewardship. https://www.jupiteram.com/uk/en/individual/about-jupiter/esg-andstewardship/ Available at [Accessed 4 Aug 2021]

[20] Khajenouri D., Schmidt J. (2021) Standard or Sustainable - Which Offers Better Performance for the Passive Investor? Journal of Applied Finance \& Banking, Vol. 11, No. 1, 2021, 61-71, Available at SSRN: https://ssrn.com/abstract $=3733811$

[21] Schmidt, J. (2017). The role of speculators in major market crashes: comparative historical analysis of the role of funds, hedge funds, leveraged institutions and other market participants in the market crashes of 1929 and 2008. Dissertation (PhD). Graz, March 2017. Available from https://unipub.uni-graz.at/obvugrhs/content/titleinfo/2157418

[22] Schmidt, J. (2001). Hedge Fund Returns: are the best times over for investors? Risk \& Reward. [Accessed 8 Aug 2021

[23] The Investment Association. Fund Sector Definitions. Available from https://www.theia.org/industry-data/fund-sectors/definitions [Accessed 4 Aug 2021]

[24] The Investment Association. (2020). The Investment Association Annual Survey. INVESTMENT MANAGEMENT IN THE UK 2019-2020. Available from https://www.theia.org > files > 20200924-imsfullreport [Accessed 8 Aug 2021] 